\title{
The cost of lung cancer in Alberta
}

\author{
Sandor J Demeter MHSc MD MSc FRCPC ${ }^{1}$, Philip Jacobs PhD ${ }^{2}$, Chester Chmielowiec MSc MD FRCPC ${ }^{3}$, \\ Wayne Logus $\mathrm{MSc}^{3}$, David Hailey $\mathrm{PhD}^{2}$, Konrad Fassbender PhD ${ }^{2}$, Alexander McEwan MB FRCPC 3
}

\begin{abstract}
SJ Demeter, P Jacobs, C Chmielowiec, et al. The cost of lung cancer in Alberta. Can Respir J 2007;14(2):81-86.
\end{abstract}

BACKGROUND: Lung cancer is the leading cause of cancer morbidity and mortality. In addition, lung cancer has a significant economic impact on society.

OBJECTIVE: To present an economic analysis of the actual care costs of lung cancer which will allow comparison with, and verification of, cost estimates that were developed through modelling and opinion.

METHODS: A chart review was conducted of incident cases (circa 1998) of primary bronchogenic lung cancer. Cases were censored at two years from the date of diagnosis. Relevant clinical and health utilization data were collected. Health utilization data included hospital and institutional outpatient (ie, ambulatory clinic) costs. Cost estimates were derived for over 200 specific health services. The present analysis was performed from the economic perspective of the health care institution.

RESULTS: A total of 13,389 health service events were captured with an estimated total cost of $\$ 8.4$ million. Laboratory tests, diagnostic imaging and ambulatory visits constituted $86 \%$ of the service events while patient admissions and therapy constituted $76 \%$ of the costs. The vast majority of overall costs occurred just before, or within, three months of diagnosis. The median nonsmall cell lung cancer and small cell lung cancer case costs were $\$ 10,928$ (range $\$ 9,234$ to $\$ 11,047$ ) and $\$ 15,350$ (range $\$ 13,033$ to $\$ 21,436$ ), respectively.

CONCLUSION: The results agree with the literature that the majority of lung cancer case costs are realized around the date of diagnosis (ie, early phase). The present study illustrates Canadian health care system lung cancer case costs based on actual care received versus hypothetical care algorithms.

Key Words: Administrative medicine; Health economics; Lung neoplasm; Oncology

\section{Les coûts du cancer du poumon en Alberta}

HISTORIQUE : Le cancer du poumon est la principale cause de morbidité et de mortalité imputable au cancer. De plus, le cancer du poumon a d'importantes répercussions économiques dans la société.

OBJECTIF : Présenter une analyse économique des coûts de santé réels du cancer du poumon qui permettra de comparer et de vérifier les estimations de coûts élaborées par la modélisation et les avis.

MÉTHODOLOGIE : On a effectué un examen des dossiers des cas incidents (vers 1998) des cancers bronchiques primaires. Les cas ont été répertoriés deux ans après la date du diagnostic. Des données d'utilisation clinique et de santé ont été colligées. Les données d'utilisation de santé incluaient les coûts hospitaliers et de consultations externes (clinique ambulatoire). Les estimations des coûts étaient dérivées de plus de 200 services de santé précis. La présente analyse a été effectuée selon la perspective économique de l'établissement de santé.

RÉSULTATS : Au total, 13389 événements de services de santé ont été colligés, pour un coût estimatif total de 8,4 millions de dollars. Les tests de laboratoire, l'imagerie diagnostique et les consultations externes représentaient $86 \%$ des événements de service, tandis que l'admission et le traitement des patients représentaient 76 \% des coûts. La majorité des coûts totaux étaient engagés juste avant ou pendant les trois mois suivant le diagnostic. Les coûts médians de chaque cas de cancer pulmonaire non à petites cellules et de cancer pulmonaire à petites cellules étaient de 10928 \$ (fourchette de 9234 \$à 11047 \$) et de 15350 \$ (fourchette de 13033 \$ à 21436 \$), respectivement.

CONCLUSION : Les résultats concordent avec les publications, selon lesquelles la majorité des coûts des cas de cancer du poumon sont engagés aux alentours de la date du diagnostic (c'est-à-dire la phase précoce). La présente étude expose les coûts des cas de cancer du poumon pour le système de santé canadien d'après les soins réels reçus, par rapport aux algorithmes hypothétiques de soins.
$\mathrm{L}$

ung cancer constitutes a burden of illness to Canadians. It $\mathcal{L}_{\text {is }}$ the leading cause of cancer-related death with a case fatality rate of $87 \%$. In 2004, the number of lung cancer deaths in Canada were estimated to be approximately 18,900. Lung cancer incidence rates are second only to prostate cancer in men and breast cancer in women (1).

In addition to morbidity and mortality rates, lung cancer also has a significant economic impact on society. Health Canada estimated that cancer as a whole constituted approximately $9 \%$, or over $\$ 14$ billion, of the total cost of illness, disability and premature death in 1998 . With respect to cancer costs, lung cancer accounted for $12.4 \%$ of total hospital care costs and $26 \%$ of total mortality costs or loss of productivity due to premature death. The 1998 combined hospital care and mortality costs for lung cancer amounted to $\$ 3$ billion (2).
To date, there have been relatively few Canadian publications on the cost of lung cancer. The majority of the Canadianbased studies are modelling studies that assume specific clinical algorithms based on best practice and/or professional surveys, hypothetical cohorts and microsimulation models (eg, Statistics Canada Population Health Model) (3).

Studies that focus on estimated total case costs (3-5) are modelled. Observational studies have tended to focus on specific interventions, such as chemotherapy $(6,7)$. For example, Jaakkimainen et al (8) published a Canadian retrospective study comparing the cost-effectiveness of chemotherapy protocols in clinical and hospital settings for advanced nonsmall cell lung cancer (NSCLC). This study was based on a randomized clinical trial cohort that was compared with a hypothetical cohort.

${ }^{1}$ Department of Radiology and Community Health Sciences, Section of Nuclear Medicine, University of Manitoba, Winnipeg, Manitoba;

${ }^{2}$ Public Health Sciences, University of Alberta; ${ }^{3}$ Alberta Cancer Board, Cross Cancer Institute, Edmonton, Alberta

Correspondence and reprints: Dr Sandor Demeter, Room GG 345, Section of Nuclear Medicine, Health Sciences Centre, 820 Sherbrook Street,

Winnipeg, Manitoba R3A 1R9. Telephone 204-787-3375, fax 204-787-3090, e-mail sdemeter@exchange.hsc.mb.ca 


\section{TABLE 1}

Patient demographics and survival results

\begin{tabular}{ll}
\hline Characteristics & \\
\hline Average age at diagnosis, years & 66.5 (range 14 to 93, SD 11) \\
Male, \% & 55 \\
Frequency of type of lung cancer & \\
by stage, \% (two-year survival, \%) & \\
Nonsmall cell lung cancer* & 74 (overall 26) \\
I & $15(83)$ \\
II & $6(63)$ \\
IIla & $10(28)$ \\
IIIb & $23(14)$ \\
IV & $37(3)$ \\
Small cell lung cancer & 17 (overall 10) \\
Limited stage & $33(22)$ \\
Extensive stage & $64(4)$ \\
Other & 9 (overall 13) \\
\hline
\end{tabular}

Total $n=611$ (58 excluded from economic analysis due to insufficient data). ${ }^{*}$ Nonsmall cell lung cancer includes adenocarcinoma, squamous cell, large cell and bronchoalveolar carcinomas; ${ }^{\dagger}$ Other includes mucoepidermoid, carcinoid, unspecified carcinoma and unspecified cancer

Coy et al (9) recently published a prospective observational Canadian-based study assessing both the cost-effectiveness and cost utility of high-dose radiotherapy for advanced NSCLC.

Lung cancer cost studies have also been performed internationally in the United Kingdom (10), Australia (11) and the United States (12). Vergnenegre et al (13) published an international review on the economic analysis of lung cancer stating that, on a macro scale, comparisons among countries is difficult due to "differences in medical practices and health care systems". They also comment on the need for continued 'microeconomic analysis' due to the ongoing advances in therapeutic interventions and associated technology needs (ie, antiangiogenesis agents).

The purpose of the present study was to present a descriptive analysis of the cost of lung cancer in a 1998 Canadian cancer cohort which was derived from actual care received. This research will allow us to verify the estimates that were developed through modelling and professional opinion.

\section{METHODS}

The study population was drawn from the catchment area of the Cross Cancer Institute (CCI) in Edmonton, Alberta, which includes the northern one-half of Alberta. Incident cases (circa 1998) of primary bronchogenic lung cancer were identified through the Alberta Cancer Registry. The descriptive epidemiology and survival analysis of this cohort has been previously published in the Canadian Respiratory Journal (14). Table 1 summarizes patient demographics and survival results for this cohort.

Data were obtained through detailed chart reviews which were conducted by experienced physicians. For validation purposes, the first 15 charts were also reviewed by the first author and no significant deviations were demonstrated.

Data were analyzed using SPSS base 10.0 (SPSS Inc, USA) software. The diagnosis date was defined as the date of most definitive diagnosis as per the Alberta Cancer Registry coding manual.

The Alberta Cancer Registry records, which are regularly updated and linked with provincial vital statistics and national mortality databases, were used to assess survival two years from the date of diagnosis. Staging for NSCLC was determined as per the 1997 revised TNM classification for staging lung cancer (15). If a separate surgical stage was recorded then the surgical stage was used, otherwise the clinical stage was used. Small cell lung carcinoma (SCLC) was recorded as limited or extensive stage based on the impression recorded by the clinician at the initial attendance at the CCI.

The present analysis was performed from the economic perspective of the health care institution. Health care utilization included hospital and institutional outpatient (ie, ambulatory clinic) events. Community health care events, such as home care, visits to primary care physicians and community-based palliative care were not captured. With respect to pharmaceutical costs, only chemotherapy costs were included.

Cost estimates were not standardized to a particular year, nor were they discounted, because the study enrollment and follow-up period were short (January 1998 to December 2000); cost estimate sources were also within the same range.

Cases were censored at two years from the date of diagnosis. Cost and utilization estimates were derived for over 200 specific health services. Broad health service categories were constructed (Table 2), and cost estimates were tabulated for selected health services (Table 3).

Unit costs for health service interventions were estimated from a number of sources including the Alberta Health Care Insurance Plan (AHIP) - 2000 Schedule of Benefits, Health Costing in Alberta - 1999 Annual Report, 2000 interprovincial rates, 2001 Regional Health Authority facility-specific rates, 2001 private diagnostic imaging facility rates and 2001 pharmaceutical catalogues. Costs were included in the analysis if the identified health service intervention was specifically related to the patient's lung cancer diagnosis or management. Costs that were clearly unrelated were not included in the final cost estimates.

For illustrative purposes, the following is an example of how the cost of a pneumonectomy was derived:

- thoracic surgeon professional fee of $\$ 933.77$ (Alberta fee schedule - code 44.5), plus

- anesthetist fee of $\$ 286.11$ (Alberta fee schedule - 44.5 ANE), plus

- estimated institutional direct and indirect costs of $\$ 8,091.47$ (Health Costing in Alberta - 1999 Annual Report which includes the weighted average of four length of stay strata based on complication category and nonphysician staff costs, as well as direct and indirect costs associated with a 'major chest procedure' refinement group number 0750-0753), equals

\section{- $\$ 9,311.35$ (total cost).}

Cost estimates were available for 128 of 154 (83\%) chemotherapy sessions. For the remaining chemotherapy protocols, which were mostly drugs undergoing clinical trials, there were no available local or international cost estimates. For these chemotherapy protocol drugs, a weighted average of the available chemotherapy costs was applied.

The present research protocol was granted approval from the Alberta Cancer Board research ethics committee.

\section{RESULTS}

Cost data were collected for 448 NSCLC cases and 105 SCLC cases. There were 10,041 health service events captured in the NSCLC cases and 3374 in the SCLC cases. With regard to health expenditures, $\$ 6,536,855$ was spent on NSCLC cases and $\$ 1,865,944$ on SCLC cases. 
TABLE 2

Health service categories

\begin{tabular}{|c|c|c|}
\hline Service category & Specific interventions included & Explanatory notes \\
\hline Ambulatory visits & $\begin{array}{l}\text { Dietician } \\
\text { Occupational therapy } \\
\text { Physician } \\
\text { Physical therapy } \\
\text { Psychology } \\
\text { Social work }\end{array}$ & $\begin{array}{l}\text { Physicians (specialist specific) were derived from the Alberta Health Care Insurance Plan (AHIP) } \\
\text { fee schedule (combined technical and professional schedule). Nonphysician costs were derived } \\
\text { from the Health Costing in Alberta (HCA) - } 1999 \text { Annual Report }\end{array}$ \\
\hline Diagnostic imaging & $\begin{array}{l}\text { Computed tomography } \\
\text { Fluoroscopy } \\
\text { Magnetic resonance imaging } \\
\text { Mammography } \\
\text { Nuclear medicine } \\
\text { Radiographs } \\
\text { Ultrasound }\end{array}$ & $\begin{array}{l}\text { There were no listings under the AHIP fee schedule for computed tomography or magnetic } \\
\text { resonance imaging. Costs for these items were estimated from the HCA report } \\
\text { (technical component) and regional health authority payments to physicians (professional } \\
\text { component). Local charges for private computed tomography and magnetic resonance imaging } \\
\text { were also considered. Local cost estimates for contrast (computed tomography) and gadolinium } \\
\text { (magnetic resonance imaging) enhancement were also factored in. All other imaging costs were as } \\
\text { per the AHIP fee schedule }\end{array}$ \\
\hline Diagnostic laboratory & $\begin{array}{l}\text { Arterial blood gases } \\
\text { Bone marrow biopsy } \\
\text { Cardiac stress tests } \\
\text { Chemistry (routine blood) } \\
\text { Cytology } \\
\text { Electrocardiograms } \\
\text { Electroencephalogram } \\
\text { Hematology } \\
\text { Histopathology } \\
\text { Microbiology } \\
\text { Pulmonary function tests } \\
\text { Specialized chemistry } \\
\text { (eg, tumour markers, } \\
\text { hormone receptor status) } \\
\text { Urinalysis }\end{array}$ & Costs were derived from the AHIP fee schedule \\
\hline Hospital admissions & Inpatient length of stay & $\begin{array}{l}\text { Costs for inpatient stays were included in the HCA report in relation to major surgical procedures. } \\
\text { For nonsurgical admission an average per day cost was derived from the HCA report as per the } \\
\text { appropriate refinement group number (which is a form of utilization per diagnostic related group } \\
\text { categorization) }\end{array}$ \\
\hline Endoscopy & $\begin{array}{l}\text { Bronchoscopy } \\
\text { Colonoscopy } \\
\text { Gastroscopy } \\
\text { Mediastinoscopy }\end{array}$ & $\begin{array}{l}\text { Costs were derived from the AHIP fee schedule and the HCA report (for facility and nonphysician } \\
\text { cost estimate) }\end{array}$ \\
\hline Therapy & $\begin{array}{l}\text { Chemotherapy } \\
\text { Oxygen therapy (home) } \\
\text { Radiotherapy } \\
\text { Surgery } \\
\text { Transfusions (blood product) }\end{array}$ & $\begin{array}{l}\text { Chemotherapy costs were derived from } 2001 \text { pharmaceutical catalogue prices. For nonlisted } \\
\text { experimental drugs, attempts were made to find a jurisdiction where the drug was licensed and } \\
\text { assigned appropriate costs. Oxygen therapy costs were derived from the Alberta government Aids } \\
\text { to Daily Living reimbursement. Radiotherapy costs were based on the Alberta Cancer Board } \\
\text { charges, per fraction, for noninsured Canadians plus a profession fee as per the AHIP. Surgery } \\
\text { costs were derived from AHIP (professional fees) plus the HCA report (facility and nonphysician } \\
\text { fees). Blood product transfusion costs were derived from the AHIP fee schedule }\end{array}$ \\
\hline
\end{tabular}

The proportion of total costs, stratified by type of health care service, are presented in Table 4. Overall, therapy and hospital inpatient costs constituted $77 \%$ and $71 \%$ of all costs for NSCLC and SCLC cases, respectively.

Table 5 further stratifies costs within the therapy and diagnostic imaging subcategories. Based on current practice guidelines $(16,17)$, surgery accounted for a higher proportion of costs for NSCLC versus SCLC and the converse is true for chemotherapy. Computed tomography scanning followed by nuclear medicine imaging accounted for $88 \%$ and $85 \%$ of total diagnostic imaging, for NSCLC and SCLC, respectively.
The average cost per case by cancer type and stage are presented in Table 6. Stage information was available in $92 \%$ (410 of 448 ) and 97\% (102 of 105) of NSCLC and SCLC cases, respectively. The median cost distribution is the most reliable estimate for cost per case because the cost distribution is skewed to the right.

The intensity of costs for all health services declined rapidly with time from date of diagnosis (Figure 1). For NSCLC and SCLC, $75 \%$ and $69 \%$ of all costs occurred between one month before the date of diagnosis and three months after diagnosis, respectively. 
TABLE 3

Cost estimates for selected health services

\begin{tabular}{|c|c|c|}
\hline $\begin{array}{l}\text { Service category and } \\
\text { specific interventions }\end{array}$ & Cost unit & Cost (\$) \\
\hline \multicolumn{3}{|l|}{ Ambulatory visits } \\
\hline \multicolumn{3}{|l|}{ Nonphysician } \\
\hline Dietician & $\begin{array}{l}\text { Per comprehensive } \\
\text { assessment }\end{array}$ & 153.00 \\
\hline Occupational therapy & Per routine session & 70.00 \\
\hline Physical therapy & Per visit session & 53.00 \\
\hline Psychology & Per visit session & 95.00 \\
\hline Social work & Per visit session & 95.00 \\
\hline \multicolumn{3}{|l|}{ Physician } \\
\hline Emergency physician & $\begin{array}{l}\text { Per comprehensive } \\
\text { assessment }\end{array}$ & 214.36 \\
\hline Family physician & $\begin{array}{l}\text { Per intermediate } \\
\text { assessment }\end{array}$ & 70.60 \\
\hline Other medical specialist* & $\begin{array}{l}\text { Per comprehensive } \\
\text { assessment }\end{array}$ & 97.47 \\
\hline \multicolumn{3}{|l|}{ Diagnostic imaging } \\
\hline Computed tomography & Per imaging scan & \\
\hline Without contrast & & 312.00 \\
\hline With contrast & & 495.00 \\
\hline Magnetic resonance imaging & Per imaging scan & \\
\hline Without enhancement & & 334.00 \\
\hline With enhancement & & 409.00 \\
\hline \multicolumn{3}{|l|}{ Hospital admissions } \\
\hline Inpatient length of stay ${ }^{\dagger}$ & Per day & 519.31 \\
\hline \multicolumn{3}{|l|}{ Endoscopy } \\
\hline Bronchoscopy & Per study & 229.48 \\
\hline Mediastinoscopy & $\begin{array}{l}\text { Per study with } \\
\text { operating room } \\
\text { facility fee }\end{array}$ & $2,081.54$ \\
\hline \multicolumn{3}{|l|}{ Therapy } \\
\hline Chemotherapy & $\begin{array}{l}\text { Cost per therapy } \\
\text { cycle (range) }\end{array}$ & $687.76-2,765.50$ \\
\hline Oxygen therapy (home) & Daily cost & 9.03 \\
\hline Radiotherapy & Per fraction & 223.47 \\
\hline Surgery & Per surgical & \\
\hline Thoracotomy $\ddagger$ & intervention & \\
\hline Wedge resection & & $8,944.53$ \\
\hline Segmental resection & & $9,271.17$ \\
\hline Lobectomy & & $9,241.77$ \\
\hline Pneumonectomy & & $9,311.35$ \\
\hline
\end{tabular}

*Medical oncologist, radiation oncologist, respiratory physician or thoracic surgeon; ${ }^{\dagger}$ General hospital admissions excluding admissions for surgical procedures such as thoracotomies, metastastectomy and abdominal surgery for obstruction; ¥Facility inpatient fees are included for thoracic surgery as per Health Costing in Alberta - 1999 Annual Report

\section{TABLE 4}

The proportion (\%) of total cost by type of health service

\begin{tabular}{lcc}
\hline Health service category* & NSCLC & SCLC \\
\hline Therapy & 46 & 40 \\
Inpatient hospital stay & 31 & 31 \\
Diagnostic imaging & 12 & 15 \\
Endoscopy & 4 & 3 \\
Ambulatory visits & 4 & 5 \\
Diagnostic laboratory & 3 & 6
\end{tabular}

${ }^{*}$ Refer to Table 2 for specific health service interventions included under each broad category. NSCLC Nonsmall cell lung cancer; SCLC Small cell lung cancer
TABLE 5

Proportion of cost in selected health service subcategories

\begin{tabular}{lcc}
\hline Health service & NSCLC & SCLC \\
\hline Therapy, \% & 39 & 38 \\
Radiotherapy & 39 & 6 \\
Surgery & 21 & 55 \\
Chemotherapy & 1 & 1 \\
Other & $3,066,043$ & 763,253 \\
Total cost, \$ & 78 & \\
Diagnostic imaging, \% & 10 & 75 \\
Computed tomography & 5 & 10 \\
Nuclear medicine & 4 & 6 \\
X-ray & 3 & 5 \\
Magnetic resonance imaging & 787,902 & 278,854 \\
Ultrasound & & \\
Total cost, \$ & SCLC Small cell lung cancer
\end{tabular}

TABLE 6

The average cost (\$) per case by cancer type and stage

\begin{tabular}{|c|c|c|c|c|}
\hline $\begin{array}{l}\text { Cancer type } \\
\text { and stage }\end{array}$ & $\mathbf{n}$ & $\begin{array}{c}\text { Mean } \pm \text { SD } \\
\text { (range) }\end{array}$ & $\begin{array}{c}5 \% \\
\text { trimmed } \\
\text { mean }\end{array}$ & Median \\
\hline \multicolumn{5}{|l|}{ NSCLC } \\
\hline 1 & 67 & $\begin{array}{l}13,380 \pm 12,173 \\
(608 \text { to } 60,360)\end{array}$ & 11,599 & 9,234 \\
\hline II & 26 & $\begin{array}{l}17,303 \pm 11,982 \\
(1,113 \text { to } 59,552)\end{array}$ & 16,033 & 14,636 \\
\hline IIla & 46 & $\begin{array}{l}18,373 \pm 11,498 \\
(1,620 \text { to } 55,559)\end{array}$ & 17,609 & 16,580 \\
\hline IIlb & 105 & $\begin{array}{l}13,663 \pm 12,512 \\
(467 \text { to } 54,063)\end{array}$ & 12,476 & 9,226 \\
\hline IV & 166 & $\begin{array}{l}15,261 \pm 13,976 \\
(480 \text { to } 81,603)\end{array}$ & 13,592 & 11,047 \\
\hline Total & 410 & $\begin{array}{l}15,023 \pm 12,976 \\
(467 \text { to } 81,602)\end{array}$ & 13,569 & 10,928 \\
\hline \multicolumn{5}{|l|}{ SCLC } \\
\hline Limited & 35 & $\begin{array}{l}22,916 \pm 15,043 \\
(1,332 \text { to } 76,928)\end{array}$ & 21,903 & 21,436 \\
\hline Extensive & 67 & $\begin{array}{l}15,802 \pm 12,280 \\
(959 \text { to } 64,424)\end{array}$ & 14,540 & 13,033 \\
\hline Total & 102 & $\begin{array}{l}18,243 \pm 13,647 \\
\text { (959 to } 76,928)\end{array}$ & 17,058 & 15,350 \\
\hline
\end{tabular}

NSCLC Nonsmall cell lung cancer; SCLC Small cell lung cancer

Figure 2 demonstrates the median costs per NSCLC case relative to the month of diagnosis with ' 1 ' representing the costs before and including the month of diagnosis.

\section{DISCUSSION}

In the present study, we conducted an analysis of the cost of lung cancer cases for all persons in northern Alberta who were diagnosed with the condition and who were treated by the Alberta Cancer Board (which represents the majority of such cases). The mean (median) costs were $\$ 15,023(\$ 10,928)$ for NSCLC and $\$ 18,243(\$ 15,350)$ for SCLC, with costs varying by stage. The majority of the costs occurred soon after diagnosis. These results gave an assessment of all persons treated, the 


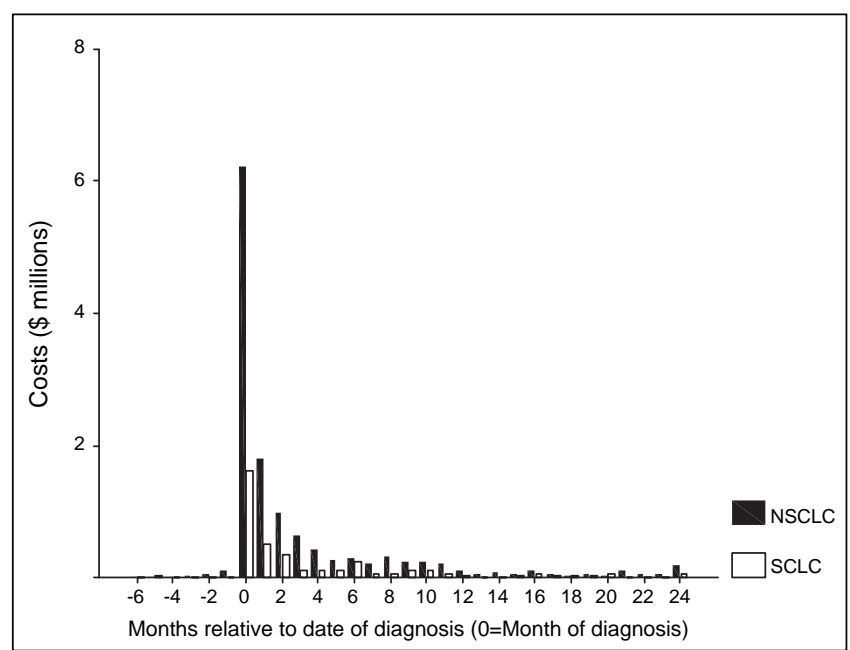

Figure 1) Costs relative to month of diagnosis. NSCLC Nonsmall lung cancer; SCLC Small cell lung cancer

course of the treatment and, thus, is an accurate assessment of costs for policy-making purposes.

Stage data were determined as per the initial oncologist consultation at the CCI. The mean interval between the initial visit to the CCI and the date of diagnosis was only 23 days (95\% CI 15 to 30 days). Thus, there was no significant bias toward upstaging of cases based on the use of $\mathrm{CCI}$ chart data.

Staging information was available for a majority of cases (ie, $92 \%$ of NSCLC cases and $97 \%$ of SCLC cases). Mean (median) case costs estimates for NSCLC and SCLC cases, where stage was not available, were $\$ 9,676(\$ 7,090)$ and $\$ 1,724$ ( $\$ 1,152)$, respectively. These case cost estimates are significantly lower than the cost estimates for cases for which stage data were available, especially for SCLC. Many of these cases had minimal information on health care interventions postdiagnosis possibly because patients never visited the CCI (ie, only Alberta Cancer Registry information available), went directly to community palliative care, elected treatment in a different cancer centre within Alberta, or moved out of the province. Cost data from the minority of cases where no stage was assigned were not included in the final case-cost analysis.

Our analysis did not capture the community-based end-of-life care. However, we were able to obtain data on end-of-life care for lung cancer cases from another source within Alberta (Edmonton and Calgary programs combined) (18), and we present the numbers here for comparison. According to this alternative data source, the cost of community care for the final 90, 180 and 365 days of life for patients with primary lung cancer was $\$ 3,013, \$ 3,890$ and $\$ 4,855$, respectively. Approximately $30 \%$ of the total cost for the last 365 days was for home care, 24\% for long-term institutional care and $46 \%$ for hospice care. Using this database, community care from these sources amounted to approximately $20 \%$ of all health care expenditures. This provided us with an estimate of the total provincial resources that were not in our estimate.

Our end-of-life cost estimates (ie, 20\% of total costs) were one-half of the literature estimates based on economic modelling. Evans et al (3) included direct health costs from 1988 from the perspective of the payer (government). Patient and

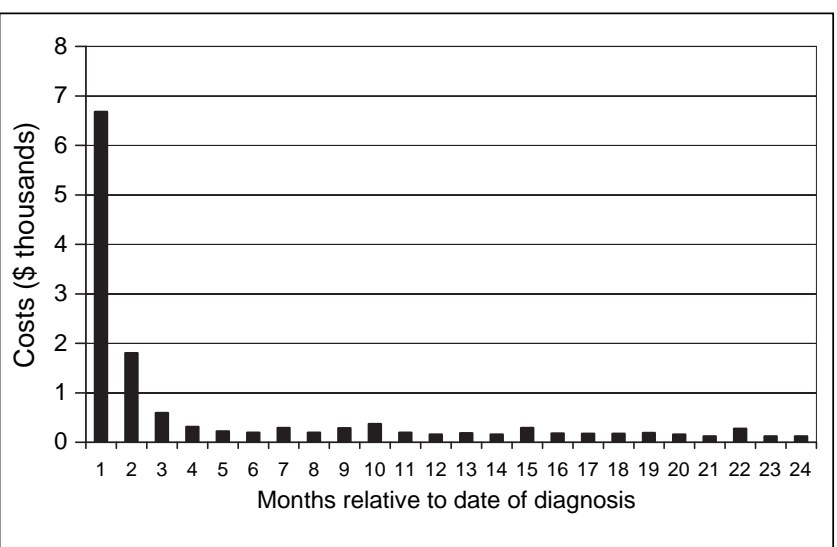

Figure 2) Median cost per nonsmall cell lung cancer case by month of diagnosis. ' 1 ' represents the costs before and including the month of diagnosis

societal costs were not included. Of the total NSCLC and SCLC costs, the 'terminal care costs' were estimated to constitute $39 \%$ of all costs. This $39 \%$ estimate for end-of-life costs may not be directly applicable to our study because it is based on modelling versus actual care costing, and palliative care in Alberta is primarily community-based which may reduce the end-of-life costs.

Cost data were collected for up to two years postdate of diagnosis or death, whichever came first. Only a minority of our cases, that is $24 \%$ of NSCLC cases and $10 \%$ of SCLC cases, survived beyond this. This would reduce the effect of censoring on case-cost estimates $(19,20)$.

In addition, there was a rapid decline in median case costs beyond three months of diagnosis. The impact of the additional costs related to the minority of our cases who survived beyond two years is thought to be minimal. This concurs with the estimates of Evans et al (3) that follow-up costs (ie, middle phase or pre-end-of-life), for NSCLC and SCLC, beyond the first year of diagnosis only constituted 3.3\% of the total costs.

Thus, for NSCLC and SCLC, the majority of costs are associated with upfront costs proximal to the date of diagnosis, which Etzioni et al (19) describe as initial phase costs.

For hospital admissions, other than major surgical procedures, we used standard general ward bed rates derived from the Health Care Costing in Alberta - 1999 Annual Report. We were not able to discriminate if such hospital admissions required general ward care or more intensive care. We may have underestimated the cost of these admissions. Such costs (ie, admissions not related to, or proximal to, major surgical procedures) constituted $31 \%$ of the total costs.

The major strength of our study is that it is based on actual care received versus hypothetical care algorithms. Clinical practice guidelines leave room for discretion at the individual case level. For example, current practice guidelines $(16,17)$ for NSCLC would include surgical cure as a primary option for stage I and II cancers and would not recommend surgery for stage IIIb and IV cancers. Recommendations for stage IIIa cancers are less polarized in primary surgery versus nonsurgery (ie, radiotherapy and chemotherapy) options. Table 7 clearly demonstrates that not all those at, or below, stage IIIa had major thoracic surgery whereas some at stage IIIb and IV did. Those with potentially curable tumours may not be candidates 
TABLE 7

Frequency of surgical interventions by stage for nonsmall cell lung cancer

\begin{tabular}{llllll}
\hline Type of surgery/stage & I & II & IIIa & IIIb & IV \\
\hline Open lung biopsy, $\mathrm{n}$ & 0 & 0 & 2 & 6 & 3 \\
Wedge resection, $\mathrm{n}$ & 5 & 0 & 0 & 1 & 0 \\
Segmental resection, $\mathrm{n}$ & 3 & 0 & 2 & 0 & 0 \\
Lobectomy, $\mathrm{n}$ & 47 & 13 & 9 & 2 & 2 \\
Pneumonectomy, $\mathrm{n}$ & 4 & 8 & 8 & 1 & 5 \\
Unspecified, $\mathrm{n}$ & 0 & 0 & 0 & 4 & 0 \\
No surgery, $\mathrm{n}$ & 10 & 5 & 25 & 92 & 157 \\
Total cases with & $57(85)$ & $21(81)$ & $21(46)$ & $14(13)$ & $9(5)$ \\
$\quad$ surgery, $\mathrm{n}(\%)$ & & & & &
\end{tabular}

Two stage I cases and one stage IV case had two surgeries each

for surgery due to comorbid conditions, and surgery may be performed in more advanced cases for reasons other than cure (ie, palliative control of local symptoms). Individual circumstances will impact decisions with respect to chemotherapy and radiotherapy.

One of the challenges in determining costs for clinical oncology services is the evolution of chemotherapy protocols and the presence of clinical trials using experimental medications, which may have no applicable cost or recognized market value. In our study, we used market (pharmaceutical catalogue) value as a cost estimator for chemotherapy agents. This would overestimate the cost because facilities can negotiate for lower catalogue prices, especially if there is a large economy of scale. However, such negotiated prices are considered proprietary and are not readily transferable among institutions. We had market values for $83 \%$ of the chemotherapy agents used in multiple lung cancer protocols. For those chemotherapy agents where no Canadian market value was readily available, cost estimates were sought in other countries where the agents may already be marketed. This yielded no additional cost estimates, and we elected to use a weighted average of the cost of chemotherapy protocols as a surrogate cost for the experimental protocols.

\section{CONCLUSION}

The present study illustrates Canadian health care system lung cancer case costs based on actual care received versus hypothetical care algorithms. This research will add to costing data available to heath care researchers, especially in the field of oncology health economics.

ACKNOWLEDGEMENT: The authors thank the Cross Cancer Institute and the University of Alberta's Radiology and Diagnostic Imaging Department - Nuclear Medicine Residency training program (Edmonton, Alberta) for their financial and in-kind support. Partial financial support was also provided through an unrestricted award (Radiant Award) from Amersham Health (United Kingdom) and through the Canada Foundation for Innovation.

\section{REFERENCES}

1. National Cancer Institute of Canada. Canadian cancer statistics 2004. <http://www.cancer.ca/vgn/images/portal/ cit_86751114/14/33/195986411niw_stats2004_en.pdf> (Version current at October 17, 2006).

2. Government of Canada. Economic burden of illness in Canada, 1998. <www.phac-aspc.gc.ca/publicat/ebic-femc98/pdf/ ebic1998.pdf $>$ (Version current at October 17, 2006).

3. Evans WK, Will BP, Berthelot JM, Wolfson MC. Estimating the cost of lung cancer diagnosis and treatment in Canada: The POHEM model. Can J Oncol 1995;5:408-19.

4. Evans WK, Will BP, Berthelot JM, Wolfson MC. The economics of lung cancer management in Canada. Lung Cancer 1996;14:19-29.

5. Evans WK, Will BP, Berthelot JM, Earle CC. Cost of combined modality interventions for stage III non-small-cell lung cancer. J Clin Oncol 1997;15:3038-48.

6. Evans WK. Cost-effectiveness of gemcitabine in stage IV non-small-cell lung cancer: An estimate using the Population Health Model lung cancer module. Semin Oncol 1997;24(2 Suppl 7):S7-56-S7-63.

7. Earle CC, Evans WK. Cost-effectiveness of paclitaxel plus cisplatin in advanced non-small-cell lung cancer. Br J Cancer 1999;80:815-20.

8. Jaakkimainen L, Goodwin PJ, Paster J, Warde P, Murray N, Rapp E. Counting the cost of chemotherapy in a National Cancer Institute of Canada randomized trial in nonsmall-cell lung cancer. J Clin Oncol 1990;8:1301-9.

9. Coy P, Schaafsma J, Schofield J. The cost-effectivness and cost-utility of high-dose palliative radiotherapy for advanced non-small-cell lung cancer. Int J Radiat Oncol Biol Phys 2000;48:1025-33.

10. Oliver E, Killen J, Kiebert G, et al. Treatment pathways, resource use and costs in the management of small cell lung cancer. Thorax 2001;56:785-90.

11. Rosenthal MA, Webster PJ, Gebski VJ, Stuart-Harris RC, Langlands AO, Boyages J. The cost of treating small cell lung cancer. Med J Aust 1992;156:605-10.

12. Esnaola NF, Lazarides SN, Mentzer SJ, Kuntz KM. Outcomes and cost-effectiveness of alternate staging strategies for non-small-cell lung cancer. J Clin Oncol 2002;20:263-73.

13. Vergnenegre A, Molinier L, Chouaid C. Economic analyses and lung cancer. Monaldi Arch Chest Dis 2001;56:336-43.

14. Demeter SJ, Chmielowiec C, Logus W, et al. The descriptive epidemiology of primary lung cancer in an Alberta cohort with a multivariate analysis of survival to two years. Can Resp J 2003;10:435-41.

15. Mountain CF. Revisions in the International System for Staging Lung Cancer. Chest 1997;111:1710-7.

16. National Cancer Institute. Non-small cell lung cancer $\left(\mathrm{PDQ}^{\circledR}\right)$ : Treatment. <http://www.cancer.gov/cancertopics/pdq/treatment/ non-small-cell-lung/patient $>$ (Version current at October 17, 2006).

17. National Cancer Institute. Small cell lung cancer $\left(\mathrm{PDQ}^{\circledR}\right)$ : Treatment. <http://www.cancer.gov/cancertopics/pdq/treatment/ small-cell-lung/patient $>$ (Version current at October 17, 2006).

18. Fassbender K, Fainsinger R, Brenneis C, Brown P, Braun T, Jacobs P. Utilization and costs of the introduction of system-wide palliative care in Alberta, 1993 - 2000. Palliative Medicine 2005;19:513-20.

19. Etzioni R, Riley GF, Ramsey SD, Brown M. Measuring costs: Administrative claims data, clinical trials, and beyond. Med Care 2002;40:III63-72.

20. Lin DY, Feuer EJ, Etzioni R, Wax Y. Estimating medical costs from incomplete follow-up data. Biometrics 1997;53:419-34. 


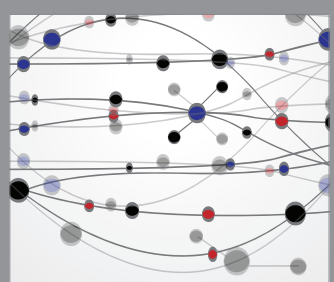

The Scientific World Journal
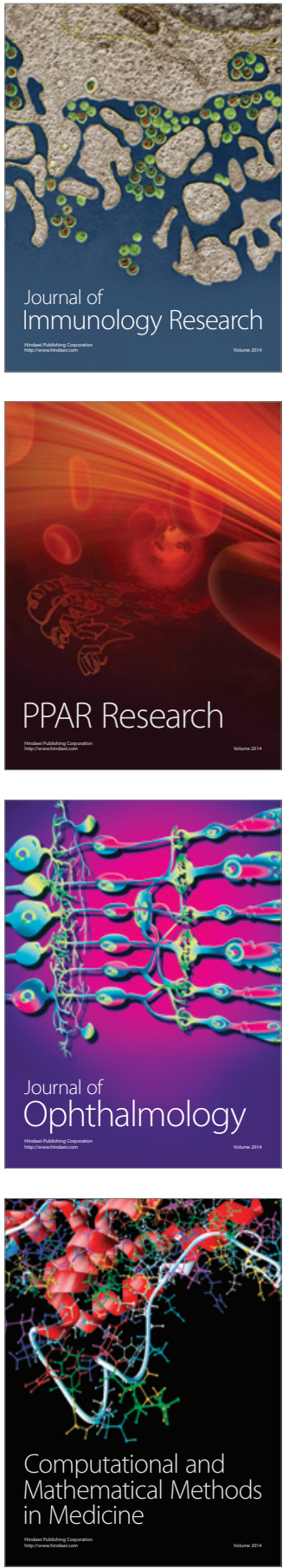

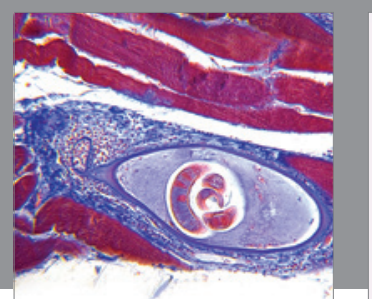

Gastroenterology Research and Practice

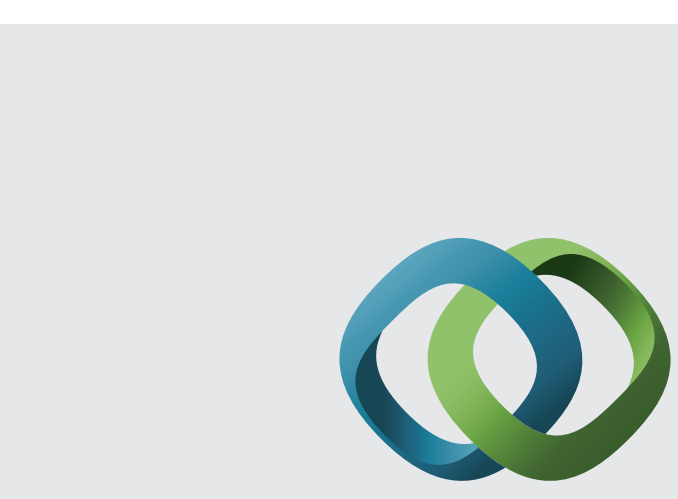

\section{Hindawi}

Submit your manuscripts at

http://www.hindawi.com
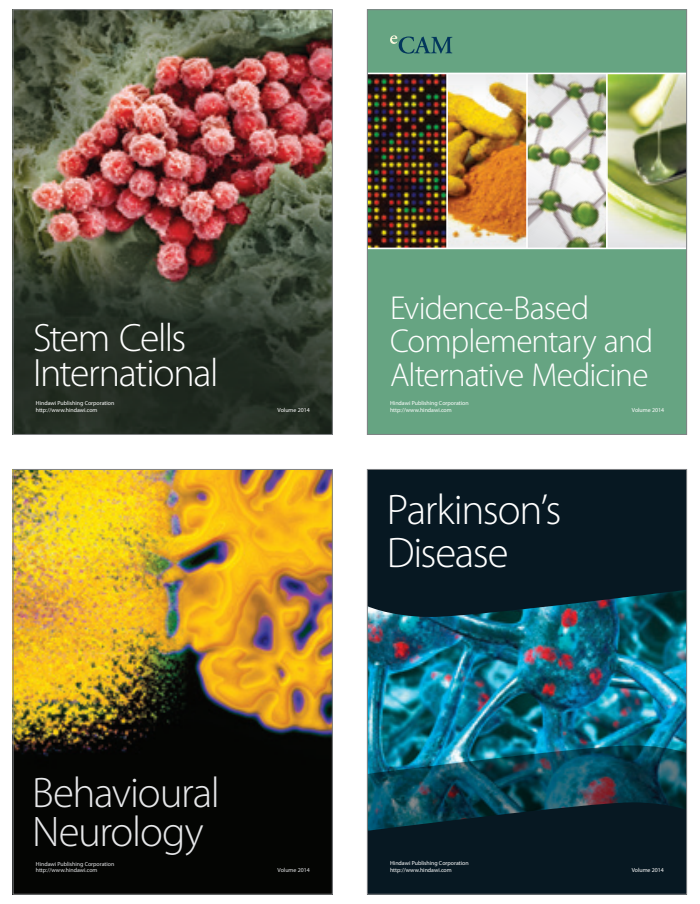
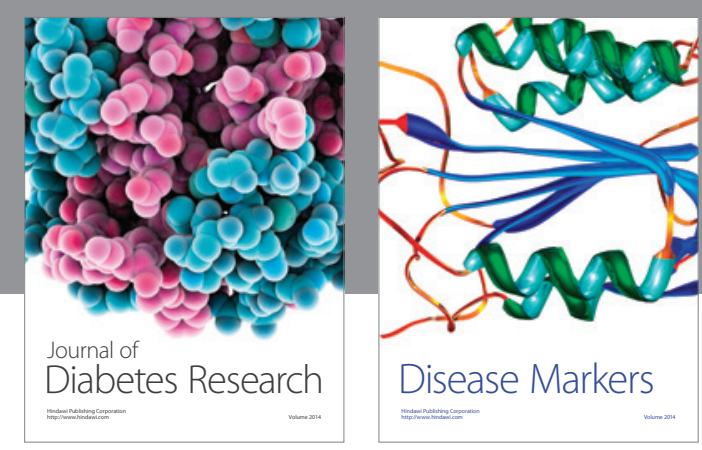

Disease Markers
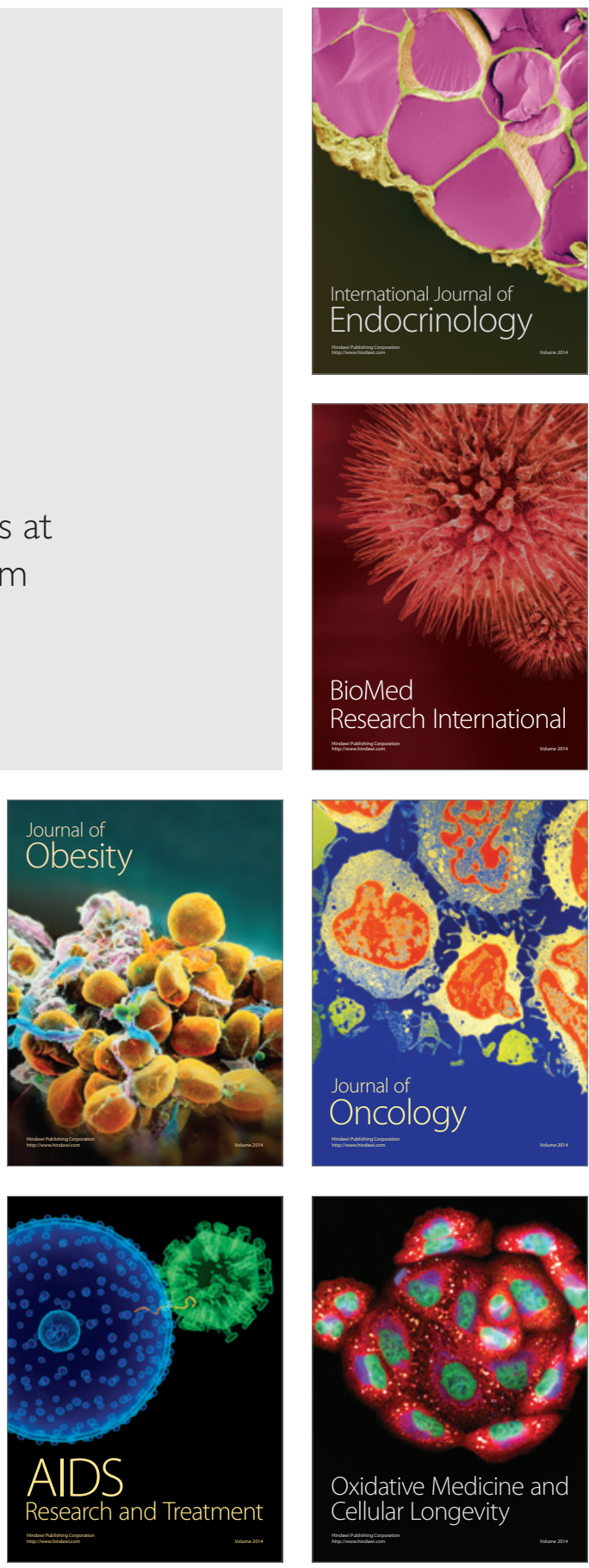